\title{
8
}
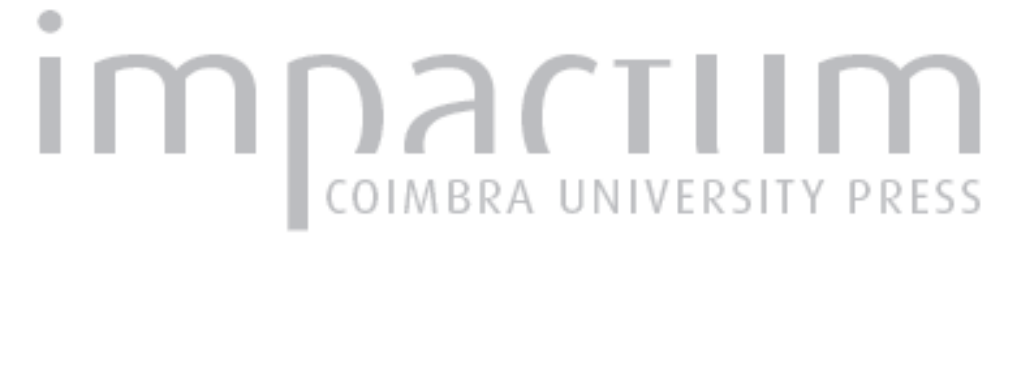

\section{Uma política da imagem: leitura antropológica da blasfémia visual a partir de Pierre Legendre}

\author{
Autor(es): $\quad$ Teixeira, Alfredo
}

Publicado por: Faculdade de Letras, Instituto de História Económica e Social

URL persistente:

URI:http://hdl.handle.net/10316.2/11967

DOI:

DOI:http://dx.doi.org/10.14195/0870-4147_40_6

Accessed : $\quad$ 26-Apr-2023 14:08:13

A navegação consulta e descarregamento dos títulos inseridos nas Bibliotecas Digitais UC Digitalis, UC Pombalina e UC Impactum, pressupõem a aceitação plena e sem reservas dos Termos e Condições de Uso destas Bibliotecas Digitais, disponíveis em https://digitalis.uc.pt/pt-pt/termos.

Conforme exposto nos referidos Termos e Condições de Uso, o descarregamento de títulos de acesso restrito requer uma licença válida de autorização devendo o utilizador aceder ao(s) documento(s) a partir de um endereço de IP da instituição detentora da supramencionada licença.

Ao utilizador é apenas permitido o descarregamento para uso pessoal, pelo que o emprego do(s) título(s) descarregado(s) para outro fim, designadamente comercial, carece de autorização do respetivo autor ou editor da obra.

Na medida em que todas as obras da UC Digitalis se encontram protegidas pelo Código do Direito de Autor e Direitos Conexos e demais legislação aplicável, toda a cópia, parcial ou total, deste documento, nos casos em que é legalmente admitida, deverá conter ou fazer-se acompanhar por este aviso.

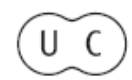



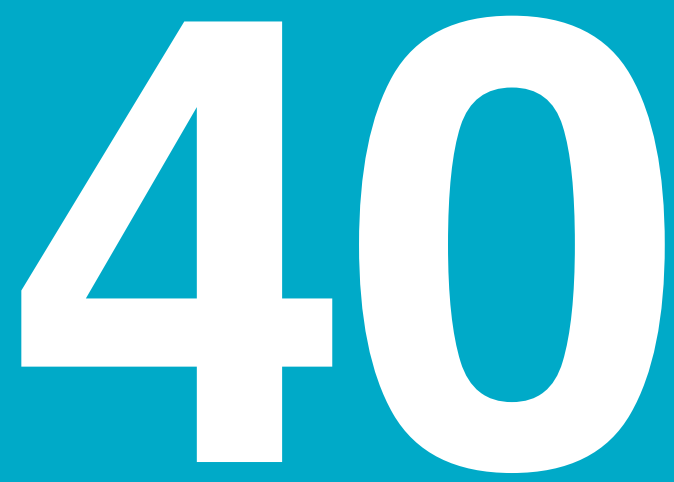

\section{Revista Portuguesa de História}

Faculdade de Letras da Universidade de Coimbra Instituto de História Económica e Social

Coimbra 08/09 


\section{Uma política da imagem Leitura antropológica da blasfémia visual a partir de Pierre Legendre}

Alfredo Teixeira Centro de Estudos de Religiões e Culturas, UCP

\section{Intróito}

As diversas texturas culturais do religioso apresentam uma grande diversidade de atitudes face às representações de natureza icónica: o aniconismo e o iconismo; a iconofilia e a iconolatria, as diversas formas de iconofobia (a iconomaquia e o iconoclastia) ${ }^{1}$. Estas classificações podem apresentar-se em várias combinações: a interdição da representação visual (em contexto de iconobofia) não se traduz, necessariamente, em estratégias de combate (iconomaquia) para destruir as imagens (iconoclastia); pode ser-se anicónico sem que isso implique a iconofobia; a iconofobia, por seu lado, não obriga à iconoclastia. É possível encontrar, nas diferentes tradições religiosas, um determinado perfil no uso de materiais icónicos, mas tal não deve fazer esquecer

*Alfredo Teixeira é Mestre em Teologia (UCP) e Doutor em Antropologia Política (ISCTE). Desenvolve a sua actividade de docência na Faculdade de Teologia e na Faculdade de Ciências Humanas da Universidade Católica Portuguesa. É investigador do Centro de Estudos de Religiões e Culturas da mesma universidade, onde actualmente coordena o projecto «Morfologia do campo religioso em Portugal».

1 Acerca destas classificações: cf. Bœspflug, 2006: 26s. 
que tais artes de fazer dependem de determinações históricas e geográficas. Uma dada tradição religiosa apresenta, em momentos diferentes, políticas diferentes quanto ao uso das produções visuais; dentro de uma mesma tradição religiosa, podemos deparar-nos com manifestações muito contrastantes, quanto aos regimes de visualidade do stock simbólico disponível.

Em termos gerais, podemos dizer que mundos diferentes, como o Egipto e a Grécia antigas ou a América pré-colombiana, apresentam muitos testemunhos de iconofilia. Por contraste, recorde-se que os chamados monoteísmos abraâmicos apresentam, de forma preponderante, tendência para a interdição da representação de Deus e, por extensão, do que dele se aproxima no sistema classificativo. Por sua vez, o hinduísmo conheceu, durante o período védico, uma fase preponderantemente anicónica e, recorde-se, o budismo desconheceu qualquer representação de Buda antes do século I a.C.

Tenha-se em conta, também, que no tocante à representação plástica do ser divino, deve distinguir-se a «questão de direito» da «questão de facto» - como oportunamente sublinhou François Bœspflug (cf. 2006: 28-30). No plano do «direito», podemos falar de um determinado estatuto icónico do ser divino, tendo em conta as montagens normativas, as construções teológicas, o costume ou os actos autorizados; mas tal perspectiva não pode ignorar a situação icónica de facto; mesmo no quadro de um estatuto icónico restritivo, a expressividade religiosa, nas diversas articulações culturais que fazem o longo curso das tradições religiosas, pode dar oportunidades inesperadas à representação plástica do divino. Os incidentes relativos à sátira visual de Maomé em 2005-2006 mostram ainda que esse estatuto icónico é também determinado por contingências históricas ${ }^{2}$.

No mês de Fevereiro de 2006, a cena pública internacional foi surpreendida com uma querela inesperada em torno de representações satíricas do profeta Maomé publicadas num jornal diário dinamarquês e reproduzidas noutros periódicos. Em Agosto de 2005, Flemming Rose, o responsável da secção cultural do Jyllands-Posten (com uma tiragem diária de 600000 exemplares) convidou para um concurso de desenhos sobre o Profeta cerca de quatro dezenas de ilustradores. A maior parte não aceitou o desafio, apenas doze enviaram um desenho. No dia 30 de Setembro de 2005, o jornal publicou os doze desenhos satíricos - pretendia-se testar a liberdade de expressão na Dinamarca. A atenção centrou-se particularmente sobre aquele em que o Profeta se apresentava com uma bomba no turbante. No dia 14 de Outubro, ou seja, quinze dias depois, nas ruas de Copenhaga, acontece a primeira manifestação desencadeada pelos

\footnotetext{
2 Uma relação mais ampla destes acontecimentos pode ser lida em: Bœspflug, 2006: 11-24.
} 
desenhos. Logo no dia 17, seis das caricaturas já publicadas aparecem num jornal do Cairo, Al Fajr, num contexto explícito de repúdio. No dia 20 de Outubro, os embaixadores de países muçulmanos, presentes em Copenhaga, assinaram uma declaração conjunta de protesto. $\mathrm{O}$ incidente não tinha ainda as proporções que viemos a conhecer - talvez, por isso, o Primeiro-ministro não recebeu os signatários deste protesto. Mas as reacções seguiam em crescendo.

No dia 29 de Dezembro, os Ministros dos Negócios Estrangeiros da Liga árabe, reunidos no Cairo, condenam o que designam de afronta aos valores do Islão. A partir do dia 10 de Janeiro de 2006, a bola de neve avoluma-se à medida que outros periódicos reproduzem os mesmos desenhos, começando pela Noruega e continuando noutros países europeus, embora com algum pudor - a percepção do risco face à ameaça terrorista terá evitado um maior número de reproduções do mesmo material visual. Alguns jornais, como o France-Soir, publicaram integralmente o conjunto dos desenhos "em nome da liberdade de expressão", atitude que enunciava já qual viria a ser o núcleo da querela. No mês de Fevereiro, mais de quatro meses passados sobre a primeira publicação dos desenhos, o espaço massmediático foi diariamente preenchido com imagens de revolta e protesto e os fóruns de debate enredados pelo dilema: liberdade de expressão (que para alguns inclui o direito à "blasfémia") ou respeito pela identidade dos outros - não se fará aqui uma análise dos contextos e recursos argumentativos, pois tal não corresponde aos objectivos deste ensaio. A leitura destes acontecimentos pode seguir três vias: a sua contextualização no plano geopolítico, tema que se afasta dos nossos propósitos antropológicos; a sua compreensão a partir do estatuto da representação icónica e plástica no interior das tradições islâmicas; a sua leitura no plano mais amplo das indagações acerca da função das representações icónicas na construção política da socialidade humana, eixo que será privilegiado neste ensaio.

Antes de avançar, não nos dispensamos, no entanto, de uma breve aproximação à economia simbólica da representação do divino nos universos muçulmanos. Neste âmbito, é necessário saber que o Alcorão não interdita explicitamente as imagens de Deus, nem as imagens em geral. Ao contrário, a Torah menciona literalmente a interdição, por exemplo, no segundo mandamento do Decálogo. Podem encontrar-se vestígios do Decálogo no Alcorão - como a sura Al'Araft (7,143-151) -, mas não é possível determinar uma dependência directa do próprio texto bíblico. O Alcorão condena sim, retrospectivamente, os ídolos pré-islâmicos. Daí que alguma da investigação mais marcante sobre a história do Islão tenha mostrado que a interdição geral da representação de «seres dotados de sopro» (abrindo uma oportunidade para os motivos vegetais) e as práticas de destruição de imagens, ou outras produções plásticas e arquitectónicas, 
que fossem objecto de culto, são essencialmente «pós-corânicas». Não se deve concluir, no entanto, que o interdito exprima uma descontinuidade com os ditos do Profeta (cf. Gimaret, 1997; Wagtendonk, 1987).

A representação plástica do Profeta tem uma história particular. Também neste caso é necessário afirmar que não existe nenhuma prescrição alcorânica que interdite imagens do Profeta. O interdito que cobriu a figuração divina e que se aprofundou após a morte do Profeta alcançou a própria figura do Profeta. No entanto, neste caso, é necessário fazer algumas distinções. Não existem representações pictóricas do profeta do género "retrato". Mas sobreviveram muitas ilustrações de tipo narrativo que representam cenas da memória islâmica fundadora. É sobretudo no universo chiita que encontraremos testemunhos de uma arte da ilustração evocativa da vida do Profeta. São particularmente célebres as ilustrações persas, que apresentam a figura do profeta com um rosto

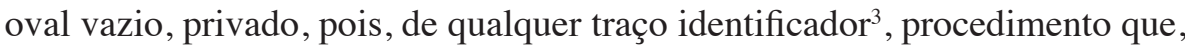
na iluminura otomana, é substituído pela prática de cobrir o seu rosto com um véu.

Sublinhe-se, ainda, que o estatuto anicónico do divino não deu origem, necessariamente, a uma espiritualidade da austeridade decorativa. A espiritualidade do Livro e da revelação abriu horizontes muito amplos para a plasticidade das artes caligráficas. Dessa forma a memória islâmica inscreve-se, cifrada, como que graffiti, em dispositivos decorativos e arquitectónicos diversos. À caligrafia junta-se a vocalidade da entoação alcorânica, traços expressivos da transcendência da mensagem ${ }^{4}$.

Esta aproximação em perspectiva permite perceber que é necessário recuar até ao problema mais vasto da imagem como espelho de uma sociedade, terreno de muitos investimentos e interdições. Como mostrou Jack Goody (1997), o medo e ambivalência face às representações é recorrente em diversas texturas culturais, incluindo os povos sem escrita. Aqui acompanharemos a antropologia do Direito de Pierre Lengendre nas trajectórias da normatividade ocidental.

3 Esta prática encontra-se documentada também na arte judaica e, mais raramente, na arte cristã (cf. Bœspflug, 2006: 509).

4 Em The Mediation of Ornament (1982), O. Grabar defende que, no contexto islâmico, as artes não figurativas têm um valor icónico. Como observa Bœspflug, por vezes, por processos de micrografia, pode ultrapassar-se o interdito desenhando com os próprios traços da escrita (cf. 2006: 46). 


\section{O princípio de “totemização” social}

\section{A Referência}

Os trabalhos de Pierre Legendre, no âmbito da antropologia do Direito, deram importância ao trabalho institucional em torno da referência ao "outro", respondente último que garante a ordem das classificações e a justeza das expectativas, isso mesmo que Legendre apelidou de função dogmática ${ }^{5}$, conceito que viria a desenvolver ao longo das suas "Lições". Nos seus estudos sobre o direito romano canonizado pela primeira Escolástica e pelo próprio direito romano medieval, Legendre pensa ter descoberto a pedra angular do nosso habitat institucional. Aí encontrou o instrumentário da montagem daquela relação constitutiva de toda a sociedade: a relação com a Referência (Référence), ou segundo uma outra expressão, com o Terceiro (Tiers $)^{6}$. Essa relação é constitutiva porque, antes de mais, coloca em cena o dispositivo estrutural que permite o acesso, sempre renovável, ao regime de autorização que enquadra qualquer processo de socialização; mas também porque delimita a própria identidade dos sujeitos enquanto indivíduos da espécie falante ${ }^{7}$. Nas manobras normativas está sempre o poder de reprodução da nossa espécie, enquanto poder de instituir a significação, dividindo as palavras e as coisas (vide Fig. 1) ${ }^{8}$.

Segundo diversos procedimentos, continuamente re-inventados, esta antropologia das instituições gira em torno das construções sociais que põem em evidência, no Ocidente, o Terceiro (divino) - mesmo quando está ausente a ideia de um Deus criador, ou quando uma cosmogonia o exclui, um Terceiro garante da divisão que institui o sujeito. As narrativas da origem, assediadas desde sempre por todo o tipo de saberes, são uma metáfora desse reconhecimento da permissão de existir que vem de um "poder doador" ("terceiro", portanto), incontornável limite donde tudo decorre (cf. Legendre, 1994: 11s, 14, 17; 1985: 169). Estamos, pois, perante o pressuposto de que os indivíduos da espécie

5 L'amour du censeur (1974) é, sob este ponto vista, a obra de Legendre mais emblemática. Michel de Certeau interessou-se por esta obra, no âmbito da sua antropologia do crer (ver o desenvolvimento crítico em: Teixeira, 2005: cap. 2)

6 Seguindo a expressão de Raymond Lemieux, poder-se-ia identificar este Terceiro com o figurante absoluto que olha (do exterior) a humanidade (cf. 1992: 178). Esta conceptualidade pode encontrar outros esclarecimentos quando confrontada com a noção de «respondente último» usada por Michel de Certeau (cf. 1981: 8-13).

7 Referência inevitável ao célebre passo de Aristóteles na sua «Política» $(1,11)$.

8 "Le Tiers instituant est toujours là, pour la manoeuvre normative d'un pouvoir indissociable de la reproduction de notre espèce: le pouvoir d'instituer la signification, en divisant les mots et les choses" (Legendre, 1994: 171). 


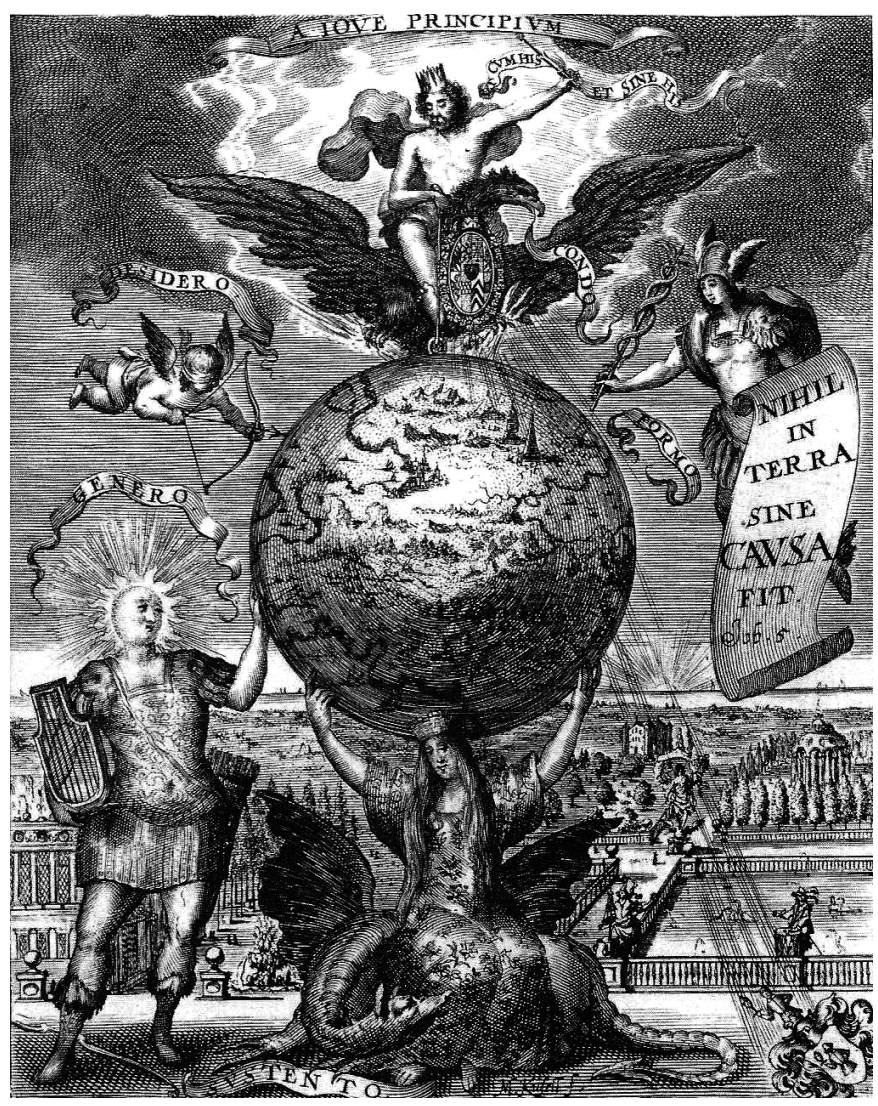

Fig 1 - Gravura alemã do século XVII (Legendre, 1985)

humana nascem imersos na indiferenciação, e que o trabalho institucional consiste na superação desse magma, abrindo caminho às possibilidades de identificação.

\section{$O$ interdito}

O que aqui está em causa é a vontade de compreender a eficácia normativa da referência aos fundamentos, espaço de comunicação entre o Político e o que, na tradição latina e depois europeia, se chamou "religio". Desde os gregos que aquilo que designamos de Político, seguindo a leitura de Legendre, é essa construção de um discurso sobre as origens do poder, enquanto discurso dominante acerca das representações do "porquê" e do fundamento da ordem 
das classificações, poder que é inseparável do imperativo de instituir a vida por meio do Interdito (cf. 1999: 33-36; 1988: 10s, 85, 327, 408).

Na sua literalidade o Interdito é um dizer, legalmente pronunciado pelo poder em função, cuja capacidade de interposição possibilita o desfecho de uma controvérsia. Num registo antropológico, Legendre define-o como o dizer que coloca em cena a palavra que se interpõe entre o sujeito e a indiferenciação originária. Mais, ele é o imperativo normativo em acção, cujo efeito social não se reduz à produção de zonas protegidas, mas se revela como dinamismo de constituição do sujeito - o campo da normatividade encontra-se penetrado pela problemática do sujeito (cf. Legendre, 1999: 27s; 81-87) ${ }^{9}$.

Legendre põe em destaque que o Interdito, motor da diferenciação, tem a vocação de notificar o sujeito acerca do limite, ou seja, a morte e o sexo; o Interdito é a negatividade em acção a partir do núcleo normativo que promove a reprodução da espécie: "A instauração do não, do desvio, significado pela proibição do incesto, irradia o sistema da cultura, porque aí se encontra a sede das representações instituídas da causalidade, a partir do porquê das leis"10. As construções normativas surgem assim como o ponto de encontro entre o indivíduo e a sociedade: de um lado, temos a exigência política de legitimação das categorias de reprodução e, do outro, a necessidade que o indivíduo tem de assumir o porquê do que o institui como sujeito. Legendre encontrará aqui a dimensão dogmática do humano que, em concreto, se exprime nessa exigência estrutural de elaboração, pelo sujeito, da sua relação com o Interdito.

\section{A instituição genealógica}

Esta construção dogmática do humano começa na inscrição de uma filiação, fundamento da instituição genealógica. Esta ordem genealógica promove a diferenciação sob a forma de distinção de lugares instituídos, segundo o eixo das filiações (ascendentes e descendentes), e estabelece as regras jurídicas necessárias à permuta simbólica que envolve as gerações - o sistema genealógico é, assim, uma construção dogmática do limite (vide Fig. 2) ${ }^{11}$. Legendre detêm-se perante um exemplo extremo inscrito no Código de Justiniano (C. 6.26.11): "pater et filius eadem esse persona" ("o pai e o

9 Sobre a fórmula vitam instituere ver - Legendre, 1999: 106-108.

10 "L'instauration du ne pas, de l'écart signifié par la prohibition de l'inceste, irradie le système de la culture, parce qu'il y a là le foyer des représentations instituées de la causalité, à partir du pourquoi des lois" (Legendre, 1999: 84).

${ }^{11}$ A amplitude da reprodução deste princípio genealógico é tal que os medievais latinos falaram da "paternidade das leis", expressão clara de que a normatividade se institui a partir 


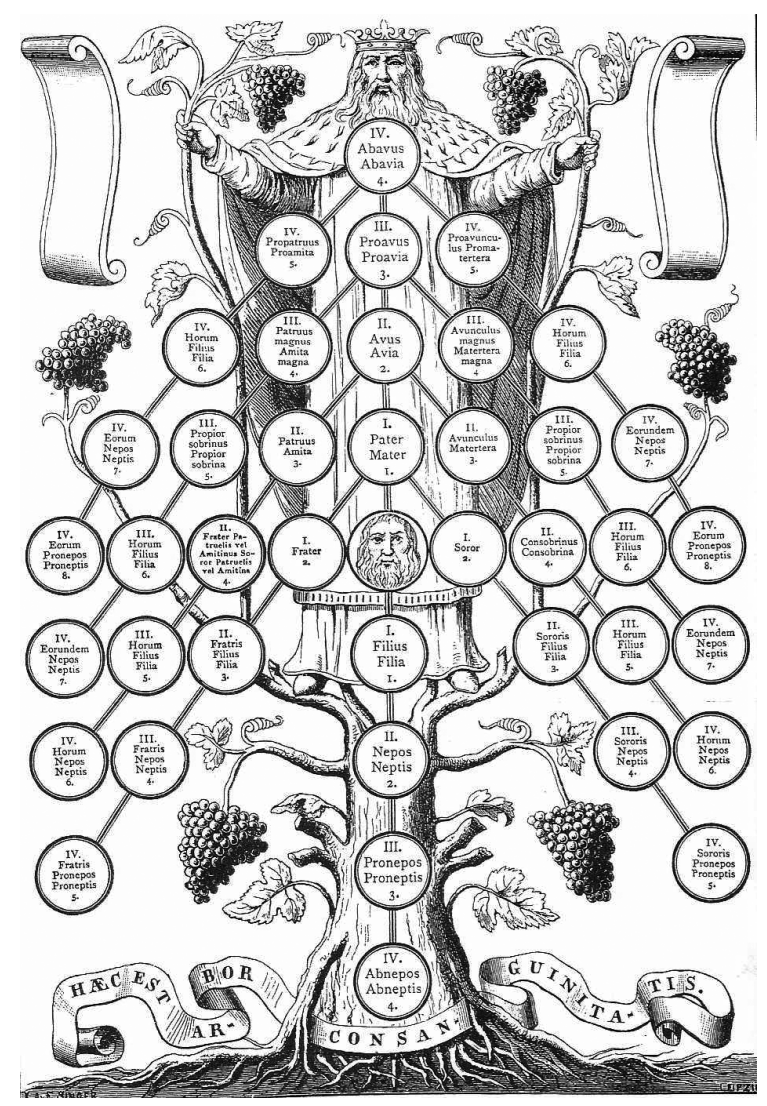

Fig 2 - “Arbor consanguinitatis", ilustração inserida depois do Decreto de Graciano na edição de Friedberg do “Corpus Iuris Canonici”, vol. I, reimp. 1955 (Legendre, 1985)

filho são a mesma pessoa"). Enunciado profusamente comentado pelos juristas ocidentais, e concretizado em múltiplas e complexas regras do direito dos bens e das obrigações, Legendre vê nele a expressão de um poder que não pode ser dividido, mas supõe a capacidade de, através do conceito jurídico de persona, se transmitir efectivamente depois da morte do pai em proveito do filho. Aqui o pai é, claramente, uma referência (pessoa jurídica ${ }^{12}$ ), ou seja, ultrapassa-se a si

da representação do Pai e da ideia de filiação, e se transmite como mensagem genealógica (cf. Legendre, 1999: 56; 1988: 43-46; 168, 371, 375;1985: 35-85; Kantorowicz, 1984: 118s, 123).

${ }^{12}$ Está aqui em causa, usando um sintagma do direito medieval romano, o estatuto de persona ficta, que a partir de figuras como Iurisdictio, Imperium, Potestas, etc., faz do Papa, do Imperador, dos Monarcas, corpos abstractos. 
próprio na sua existência limitada, e apresenta-se com um estatuto de ficção a que o seu filho terá acesso ${ }^{13}$.

Estas observações de Legendre dependem desse olhar psicanalítico onde o pai surge como o "terceiro" face à relação incestuosa do filho com a mãe, ou seja, o pai ultrapassa-se como pessoa física e torna-se uma função - enquanto tal, é uma forma vazia que pode ser manipulada por qualquer sistema jurídico. A República, o Estado, Deus, o Povo, são nomes para esse respondente último que funda a ordem dum sistema - economizando, poderíamos falar da função monoteísta ${ }^{14}$. As políticas de nominação foram muitas, sob o desígnio do mito andrógino ocidental, sob o símbolo duplo da Mãe Igreja e do pontífice omnisciente, ou em tríades como "Deus, Roma, Direito" ou "Deus, Pátria, Família". Mas são sempre testemunhos das transformações da representação da relação com a Referência. A historiografia tornou patente que, na economia de um sistema dogmático chamado a reproduzir-se, a caducidade afecta as formulações, ou seja os conteúdos, mas não o princípio estrutural da sua reprodução: o princípio de totemização da sociedade (vide Fig. 3$)^{15}$.

A documentação apresentada por Pierre Legendre, permite perceber que o juridismo que informou a política na Europa ocidental testemunha que, em matéria de Referência não há lugar para mais do que um. Estas tríades devem ser vistas, por isso, como desdobramento do princípio do Pai totémico, o que não impede que a partir desse fundamento único não nos deparemos com montagens de diferentes níveis hierárquicos (cf. Legendre, 1988: 242s). Nesta linha refiram-se as distinções entre espiritual e temporal e entre eclesiástico e laico, ou leigo, cujos efeitos teóricos e institucionais se podem encontrar na "teoria da duas espadas", ou nas formas modernas de divisão de poderes.

${ }^{13}$ Mas interessa não esquecer que, como o próprio Legendre sublinha, que este poder da família é constituído a partir duma legitimação de recorte político - a função do pai no direito romano está estreitamente ligada às constituições do poder na cidade, ou seja, o conceito de pater familias não é separável da qualidade política exprimida pelo título de civis (cidadão) (cf. Legendre, 1999: 56; 1985: 171s, 175-178).

${ }^{14}$ Legendre concede uma particular atenção à função paternal do Estado moderno: "Les États modernes sont en position structurale de parents, c'est-à-dire de garants de l'idée du Père à l'égard des ressortissants de la normativité industrielle, et que derrière le racisme se profile un enjeu d'extermination de jeunes générations immigrées dans l'ordre du politique généalogique. Or, cet enjeu est tout à fait apparent dans les discussions classiques sur la nationalité, quand il s'agissait pour les États de s'adjuger leurs nationaux dans la perspective, encore peu sécularisée, de la paternité politique si longtemps confondue en Europe avec ce que nous appelons de nos jours l'appartenance confessionnelle" (1988, 329-330; cf. ibid. 271-287).

${ }^{15}$ Estas observações vão na linha da definição da "dogmaticidade" como "lei de conservação" (Legendre, 1974: 250) 


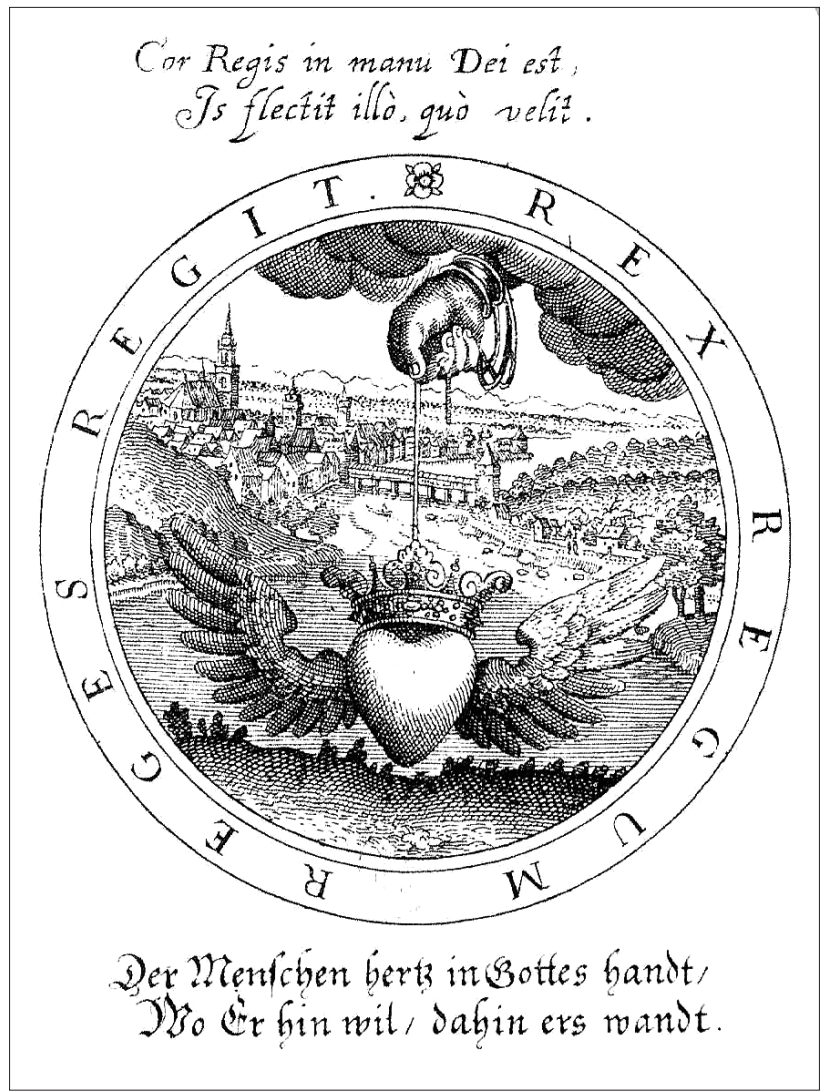

Fig 3 - Brasão extraído de J. Bornitius, Emblematum Ethico-Politicorum, 1664: "Rex Regum Reges Regit" - O Rei dos Reis governa os Reis (Legendre, 1997)

Esta modalidade de classificação toca directamente os fundamentos europeus modernos da Religião e da Política. Assim o prova a persistência da disputa e da permuta entre si dos fundamentos do poder: o direito à última palavra, o privilégio do sentido do humano, a cena original que permite identificar o bem, o gesto doador, etc.

A função dogmática que aqui se desenha tem, assim, por base aquela operação de crédito sem a qual não seria possível a encenação da "Referência terceira" (Référence tierce), que nas chamadas religiões abraâmicas se consubstancia na ideia de Revelação e na teatralização social que a traduz. A abordagem de Legendre permite pôr em evidência o facto de toda a Referência funcionar como "discurso-credor", instância à qual se paga a dívida da ritualidade, e instância que garante das imagens fundadoras das filiações - daí o carácter primordial 
das figuras do Muttertum e do Vatertum. Estamos perante as montagens institucionais religiosas familiares à cultural ocidental europeia, como a Torá, o Livro, o Testamento cristão, que põem em acção o princípio genealógico. Ou seja, instituem o discurso da verdade fundadora, cuja ritualização está na base do princípio de Estado difundido na Europa, por via do cristianismo pontifical e do direito romano imperial - não é pois de espantar que a religião latina esteja no centro das montagens da comunicação dogmática no Ocidente ${ }^{16}$.

\section{$O$ «emblema»}

Este trabalho no terreno da normatividade exige uma outra operação social: o reconhecimento. Ora as condições formais que determinam a conformidade de um acto autorizado escondem as condições sociais que produzem o reconhecimento desse acto enquanto tal. Só essas condições permitem o discurso soberano - segundo as observações de Legendre, a Soberania -, ou seja, essa qualidade dos que podem falar em nome próprio, uma vez que são o lugar-tenente desse sujeito ideal que é a Referência instituidora. Só através das bocas autorizadas esse corpo ficcional pode falar ou adquirir o estatuto de corpo falante - dvee aqui falar-se de um trabalho de "emblematização" do sujeito ${ }^{17}$.

Tal trabalho social pode ser resumido numa das fórmulas centrais dos estudos de Kantorowicz reunidos em The King's Two Bodies: dignitas non moritur (a dignidade - ou seja, a função - não morre), emblema que resume o sentido de perenidade suposta das instituições, que permite o desdobramento institucional do sujeito ("os dois corpos do rei”): o soberano e a sua função, unidos numa espécie de matrimónio místico. Estes estudos têm o mérito de pôr em destaque a necessidade do elemento mitológico à vida institucional, elemento que permite essa divisão do monarca: o seu corpo real, por um lado, e por outro, o corpo de ficção, em razão do qual o rei acede ao estatuto de representação legal da estrutura $^{18}$. O dossier reunido por Kantorowicz em torno da máxima escolástica

${ }^{16}$ De acordo com os estudos de Legendre é possível explorar a hipótese de que a instituição eclesiástica foi portadora do princípio de organização que se veio a chamar Estado - lugar de verdade e lugar de poder (cf. Legendre, 1999: 39s,51, 86; 1988: 110, 222, 223).

${ }^{17}$ Aproxime-se a metáfora da própria etimologia: "emblema", aquilo que é aplicado, embutido, encrostado, incorporado, no ferro ou na madeira (cf. Legendre, 1999: 25, 51s, 55). $\mathrm{O}$ argumento emblemático é particularmente discernível no âmbito do discurso fundador, cujo estatuto não é o da demonstração, mas o da palavra-emblema, ou seja, a palavra articulada para ser vista (cf. 1988: 224). Esta metáfora aproxima-se de uma outra, a do "sujeito monumental", ou seja, o sujeito reescrito pelas instituições enquanto sua própria representação (cf. 1999: 45).

${ }^{18}$ Kantorowicz desenvolve este tema no Cap. VII da obra citada. Ver também o comentário de Legendre em Leçons II (1983: 19). Legendre desenvolveu estes pressupostos nas suas lições 
que visava o Imperador e o Papa: omnia iura habet in scrino pectoris sui ("tem todos os direitos no arquivo do seu peito"), é um bom exemplo deste trabalho de ficção que está na base das montagens institucionais. Entre as várias glosas, Kantorowicz comenta aquela que esclarece que a máxima se refere à corte de doutores sábios por cuja boca fala o mestre do direito (cf. 1957: 24s, 153s). A Alteridade surge, assim, na ficção, no território do fantástico (cf. Certeau, 1973: 177; Lemieux, 1992: 178-181).

Os estudos de Legendre permitem dar profundidade histórica a algumas das considerações de Bourdieu sobre os actos de palavra (cf. 1982), na medida em que fornecem inúmeros exemplos, retirados da história jurídica do Ocidente, das montagens que colocam em cena a sociedade como corpo falante, corpo artificial dotado de palavra - liberal ou tirânico, nenhum sistema dispensa um modo instituído de distribuição da palavra. Legendre refere-se em concreto à omnipresença da metáfora orgânica, na Idade Média, para falar das instituições, enquanto dotadas de palavra. O Ocidente parece, pois ser, atravessado pela problemática do fundamento do dizer, inquietude que repousa em figuras mitológicas muito diversas e em identidades colectivas juridicamente constituídas como "corpo" (cf. Legendre, 1988: 28, 33-40) ${ }^{19}$.

\section{$O$ rito}

A "hipótese do Terceiro", como a colocou Legendre, pode contribuir para a superação do impasse que se experimenta quando se promove a redução das relações de crença e de crédito, que se traduzem no rito, a um modo de comunicação dual entre a instituição autorizada e a disposição crente. As referên-

sobre "os dois corpos do pai": "Considérons donc les deux corps du père. Structuralement parlant, si le père est pensable en termes de pouvoir - souvenez-vous ici des interrogations de Freud à propos du Totem -, c'est que ce pouvoir ne se confond pas avec celui qui l'exerce, mais relève d'une fonction bien précise: la fonction de différencier (un enfant, de sa mère) par le jeu de la Référence. Le père est celui qui réfère l'enfant à la Référence, en tant que celle-ci notifie la différenciation d'avec la Mère à majuscule. Nous voici de nouveau en présence du jeu complexe de la Référence, que j'ai appelé jeu croisé des fonctions, parce que l'idée du Père en elle-même n'est concevable que si l'idée de la Mère est de la partie. Mais avant de tirer profit de cette remarque, notons ceci: du point de vue de l'ordre généalogique, un père-individu ne tient pas sa place arbitrairement, il la tient au nom de [...]; il n'est pas un propriétaire d'enfants, car il fonctionne - retenons le jargon d'aujourd'hui, ici adéquat: fonctionner - comme fonction du Père, autrement dit il représente la substance du père, la représentation mythologique du Père telle qu'une société la déclare en tel instant de l'histoire" $(1988,280)$.

19 A leitura do estudo de Y. Labbé sobre o monoteísmo ocidental (La Parole-Icône incréée) é uma eloquente testemunha teológica desta discussão (cf. 1984). 
cias medievais fornecidas pelo autor permitem enunciar a hipótese de que não há gesto ritual que não seja referido: a ritualidade só é praticável na relação com a "referência" que a acredita. Esta relação exprime-se na teatralidade própria do rito, em particular, nas diversas montagens do "em nome de" ("no nome de") - este é, aliás, o ponto em que se articulam ritos e mitologias, uma vez que estas pretendem superar o não-dito da ritualidade, fixando as origens e os efeitos do "em nome de". Esta observação permite supor que é a relação com a Referência que confere ao rito o poder de classificar. Ou seja, é o seu valor emblemático - representação do Emblema absoluto - que o torna eficaz face ao perigo social da indiferenciação (no sentido girardiano), uma vez que nele se representam as diferenças, as hierarquias, as genealogias, etc. ${ }^{20}$. No caso das Igreja latinas, a ordem ritual canónica traduz-se numa encenação do Emblema absoluto, da Soberania, de que a figura do Pontífice romano é a encarnação mais sublime. Daí a importância das manobras jurídicas que excluem a parte maldita da ritualidade (ilegal) - é que a ritualidade não pode ser fechada nos códigos da semiótica, ela tem que ser olhada sob o ângulo político, ou seja como representação do poder. Às manobras jurídicas é necessário juntar as práticas

${ }^{20}$ Girard sublinhou o facto de certos ritos acontecerem no seio de festas que põem em acção a crise mimética (cf. 1972: 179). Nos seus rituais as sociedades primitivas abandonam-se voluntariamente àquilo que receiam no resto do tempo: a dissolução mimética da comunidade. Se os interditos são anti-miméticos, todo o pôr em acção a crise mimética consiste, necessariamente, em violar os interditos. Tais festas geram, portanto, uma espécie de derrocada conflitual da organização cultural. No paroxismo desta crise os homens disputam violentamente os objectos quotidianamente interditos; por isso, encontramos, no seio de tais fenómenos, o incesto ritual, a fornicação com mulheres que não se podem tocar no resto do tempo (cf. 1978: 29) - o rito no contexto destas festas aparece como o verdadeiro verkehrte Welt, o mundo às avessas. O paradoxo da aparente contradição entre rito e interdito tem a seguinte explicação: os interditos impedem que o pecado original se produza; os ritos têm por finalidade reparar os danos quando tal pecado se produza. Há entre os dois a diferença entre o tratamento profilático e o tratamento terapêutico de uma mesma doença. Para percebermos isto não podemos perder de vista a tese central de Girard, concretizada na afirmação de que todo o rito reproduz o mecanismo fundador. Basta observar como não há rito que não conclua com imolações, mutilações rituais, exorcismos, etc., que equivalem sempre ao sacrifício, põem em acção o mecanismo vitimário (cf. Girard, 1978: 32-34). Também aqui o método girardiano de reduzir o fenómeno humano a um princípio único se concretiza nesta explicação única para a diversidade fenomenológica dos ritos, sejam eles ritos de passagem, ritos baptismais ou transes rituais: são sempre banhos de indiferenciação dos quais se sai mais diferenciado - operando, frequentemente, uma mudança de estado - e reproduções da inter-individualidade que caracteriza as crises sacrificiais (cf. 1978: 37, 48; 1972: 379-428). Repetindo mimeticamente uma crise mimética original, o rito é mimêsis, mas difere fundamentalmente da desordem, pela unanimidade em que se enraíza; a mistificação ritual é, precisamente, a ocultação do desejo mimético (cf. 1982: 207s). 
de erudição que dizem os "porquês" das coisas rituais e que acabam por fazer parte da própria ordem cénica do rito (cf. Legendre 1988: 403-407).

Na conhecida hipótese de René Girard acerca das origens do sagrado social (no sentido durkheimiano), a hipótese do bode expiatório, documentada em múltiplas narrativas de linchamento colectivo ${ }^{21}$, a ritualidade humana é compreendida no quadro da ideologia sacrificial, como recurso profiláctico, visando a manutenção da ordem e da paz. Numa das narrativas recolhidas por René Girard (cf.1999: 83s), a produção da imagem divino encontra-se no próprio desenlace do processo do bode expiatório, enquanto representação ambivalente do medo de dissolução social e brasão da identidade colectiva. A narrativa que tem como protagonista Apolónio de Tiana, filósofo itinerante grego - como que um pregador-taumaturgo - que difundiu as ideias neopitagóricas por várias cidades romanas (97 d.C.).

"Hoje mesmo vou acabar a epidemia que vos oprime". Com estas palavras, ele [Apolónio de Tiana] conduziu todo o povo ao teatro onde uma imagem do Deus protector estava levantada. Ele viu lá uma espécie de mendigo que fechava os olhos como se fosse cego e transportava uma bolsa com uma côdea de pão. $\mathrm{O}$ homem, vestido de trapos, tinha algo de repelente.

Os Efésios dispuseram-se circularmente à sua volta e Apolónio disse-lhes: "Juntai quantas pedras puderdes e lançai-as contra este inimigo de Deus. Os Efésios perguntavam-se onde queria ele chegar. Escandalizavam-se com a ideia de matar um desconhecido manifestamente miserável que lhes pedia e suplicava piedade. Voltando à carga, Apolónio incitava os Efésios a lançarem-se sobre ele para impedir que ele se afastasse.

Assim que alguns lhe seguiram o conselho, lançando pedras ao mendigo, ele, cujos olhos fechados faziam pensar que fosse cego, logo lançou um olhar penetrante, mostrando os olhos cheios de fogo. Os Efésios reconheceram então que se tinham preocupado com um demónio e lapidaram-no com tanta vontade que as suas pedras formaram um grande túmulo em torno do seu corpo.

Depois de breves momentos, Apolónio convidou-os a retirar as pedras para reconhecerem o animal selvagem sobre o qual as tinham lançado, e constataram que não era o mendigo. No seu lugar, estava um animal que parecia um canzarrão, tão grande quanto o maior leão. Ele estava ali sob os seus olhos, reduzido pelas sua pedras ao estado de pasta e vomitado como aquela baba dos cães enraivecidos. Por esta razão, levantou-se uma estátua

${ }^{21}$ Ver a nossa abordagem crítica - Teixeira: 1995. 
do Deus protector, Hêrakles, no próprio lugar onde o espírito mau tinha sido expulso ${ }^{22}$.

Se observarmos cada uns dos mitemas do primeiro relato depressa descobrimos os esteriótipos da engrenagem da violência colectiva, aqui desenhada num processo de lapidação: o grupo numa situação de crise, afectado por uma epidemia (um dos perigos mais ameaçadores para as sociedades antigas e medievais); a proposta de uma solução vitimária e designação de uma vítima; a qualidade de marginalidade da vítima; a sua desfiguração/desumanização; o contágio mimético que conduz à violência da multidão sobre a vítima desumanizada; o processo de sacralização da violência através de um processo de transferência daquela violência para a esfera divina (ambivalência poder maléfico/poder benéfico). A narrativa começou evocando a presença de uma imagem do Deus da "polis" e termina com a indicação de que foi levantada uma estátua ao Deus protector. A função totémica do sagrado consiste aqui nesse poder emblematizador da identidade que as representações figuradas do divino traduzem - a imagem vigia sobre os interditos necessários à sobrevivência da comunidade e comemora o advento da paz que superou a destruição epidémica. Não é assim difícil perceber que os conflitos entre os povos se apresentem, com frequência, sob a figura da iconoclastia. Não espanta também que, quando a sátira religiosa encontrou vias facilitadas nas sociedades cristãs, o humor - porque torna visível a estrutura ${ }^{23}$ - procure o desvelamento dessa assimilação da violência divina à violência humana (vide Fig. 4).

\section{A imagem e a função do Terceiro (Tiers) nas sociedades secularizadas}

\section{"Imago"}

Pierre Legendre resume em três regiões semânticas o sentido de imago no processo de totemização social (cf. 1994; 1999: 301s). Na primeira região, é necessário recuar à infância do humano e tomar em consideração a função do brinquedo enquanto objecto "transicional": neste sentido, a imagem dá figura à separação, é incarnação do objecto separador. Numa segunda região, imago diz respeito aos antepassados - exemplo acabado, a máscara mortuária. Em Roma, passeava-se em procissão a imagem do defunto, em contexto de homenagem

${ }^{22}$ Traduzido a partir de: Flavius Philostratus, The Life of Apollonius of Tyana. The Epistles of Apollonius and the Treatise by Eusebius, Cambridge, Harvard University Press.

${ }^{23}$ A este propósito: cf. Girard, 2002: cap. VIII. 


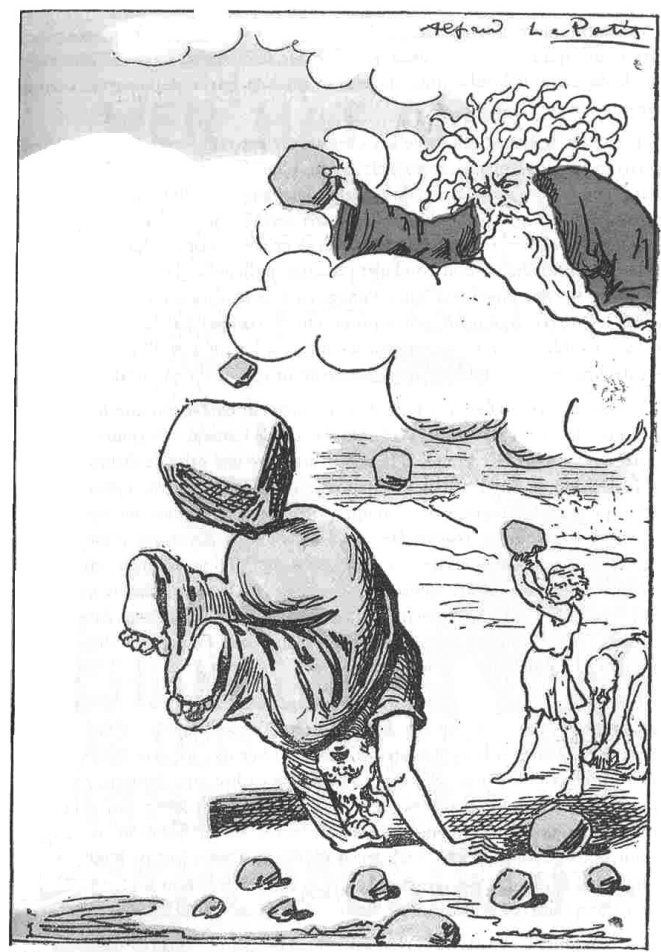

Il arriva ensuite qu'un homme blasphéma. Et le Seigneur, consulté par Moïse, dit: "Que cet homme soit lapidé, " Et le coupable fut lapidé...

Fig 4 - Ilustração satírica de Lev 24, 13s ${ }^{1}$, da autoria de Albert le Petit (Doisy, 2006: 87)

fúnebre; as ritualidades políticas não dispensam o culto dos antepassados fundadores, do qual faz parte a mise en scène das imagens do rei, do libertador, do revolucionário, etc. - dos funerais reais às cerimónias na Praça Vermelha na ex-URSS, deparamo-nos sempre com o problema do poder como imagem ou da imagem como presença do que é imortal no poder. A terceira região semântica de imago apresenta-se sob o signo do paradoxo: a imagem do que não pode ser visto ou representado, mas deve ser encenado. Este é, segundo Legendre, o território das grandes querelas, onde a humanidade se divide em clãs inconciliáveis. O exemplo mais significativo, no universo cristão, pode identificar-se nas disputas cristológicas do Cristianismo antigo, terreno de tensões teológicas que

1 «O Senhor falou assim a Moisés: "Faz sair o blasfemo para fora do acampamento: todos os que o ouviram imponham as mãos sobre a sua cabeça, e que toda a comunidade o apedreje"». 
terão uma ampla posteridade. A pergunta essencial dizia respeito à necessidade de se estabelecer se Jesus Cristo seria uma aparência na sua humanidade. A resposta tinha consequências importantes no que concerne à morte de Jesus. Entre os evangelhos não canónicos, encontramos um texto, o chamado pseudo-Barnabé, que procura dar sustento ao pressuposto fundamental de que Deus não pode morrer; para tal, Jesus é substituído na cruz por um duplo, Judas. A iconografia do crucificado tornou-se o testemunho mais eloquente da teologia realista: ao emblema abstracto da cruz, vai preferir-se a teatralização do corpo de Jesus cravado na cruz.

\section{O Estado moderno}

Neste desdobramento hermenêutico, imago remete para o substrato da actividade simbólica humana, enquanto capacidade de "substituir". A imagem é presença de algo na sua ausência, tal como a palavra, e por isso deve ser compreendida no terreno da instituição das relações de significado compreende-se assim que ela seja o cerne de muitas montagens normativas (cf. Legendre, 1999: 304s). Nas trajectórias da modernidade europeia, boa parte deste trabalho institucional-normativo foi transferido para para o Estado moderno. Mas a mudança de órbita da construção do social não implica a obsolescência do sagrado, já que este é a figura nuclear do problema do Terceiro (Tiers) separado. Se no monoteísmo religioso, Deus se reveste das funções do Terceiro (Tiers), o que acontece nas sociedades secularizadas e nas formas políticas laicizadas ${ }^{24}$ ? Para Legendre, o Estado moderno foi construído, precisamente, sobre os alicerces do conceito romano-canónico de religio $^{25}$ (em particular, a aculturação da religio romana no cristianismo latino ${ }^{26}$ ).

Neste terreno, pode estabelecer-se uma fecunda proximidade entre Pierre Legendre e Michel de Foucault, em particular, no que toca à relevância das considerações deste sobre o "poder pastoral". Foi Michel Foucault quem mais chamou a atenção para a importância dessa nova arte do poder. Mais do que em mandamentos dirigidos a uma totalidade abstracta, ela assenta na capacidade de

${ }^{24}$ Acerca do conceito de secularização: cf. Tschannen, 1992; Dobbelaere, 1981.

25 "La sécularisation ne sera comprise et assimilable, que si comprend d'abord le concept de religion. Pour cela, il faut secouer nos habitudes de pensée. Nous vivons non pas la fin des Lumières, mais la fin du Moyen Âge, de cet instant historique où ont jetées les bases du Tiers abstrait qui va succéder le christianisme: en inventant la notion d'État. Le concept romano-canonique de religion doit être d'abord compris, si l'on veut comprendre l'État sécularisé; il y a là un préalable" (Legendre, 1999: 309; cf. 305-307).

${ }^{26}$ A este propósito consulte-se: Sachot, 1998. 
dirigir as singularidades. Assim, a competência essencial desse poder concretiza-se na capacidade de intervir nas consciências - daí a importância histórica das práticas da "confissão" na organização das ortodoxias e ortopraxias cristãs. Foucault interessou-se pelas formas de poder que denominou de "governo pela individualização". Este poder que se exerce sobre a vida quotidiana classifica os indivíduos em categorias, designa-os pela sua individualidade própria, fortalece-os na sua identidade, impõem-lhes uma verdade que devem reconhecer e que os outros devem reconhecer neles. É, portanto, uma forma de poder que transforma os indivíduos em sujeitos. "Sujeito" em dois sentidos: pode ser o sujeito submetido ao outro, sob o seu controlo e na sua dependência, e pode tratar-se do sujeito que investe na sua identidade pela via da auto-consciência ${ }^{27}$.

Na nova estrutura política que se desenvolveu na Europa a partir do século XVI, o Estado é visto frequentemente como um tipo de poder político que ignora os indivíduos, cuidando apenas os interesses da comunidade. Ao contrário, Foucault procura mostrar que talvez nunca tenha existido uma combinação tão complexa de técnicas de individualização e de procedimentos totalizantes. O Estado moderno terá incorporado uma velha técnica de poder nascida nas instituições cristãs, o "poder pastoral". Enquanto Igreja, o cristianismo postula uma teoria segundo a qual certos indivíduos estão aptos, pelas suas qualidades religiosas, a servir os outros enquanto "pastores" 28 . Este poder pastoral pode, assim, ser compreendido a partir de quatro determinações fundamentais: 1) $o$ objectivo final deste poder é assegurar a salvação dos indivíduos na vida que há-de vir; 2) não apenas como um poder que ordena, mas como aquele que leva o pastor a dar a sua vida pela vida das suas ovelhas; 3 ) trata-se de uma forma de poder que não visa apenas o conjunto da comunidade mas cada indivíduo, e durante toda a sua vida; 4) este poder não seria efectivo se não implicasse o conhecimento das consciências.

27 "C'est une forme de pouvoir qui transforme les individus en sujets. Il y a deux sens au mot sujet: sujet soumis à l'autre par le contrôle et la dépendance, et sujet attaché à sa propre identité par la conscience ou la connaissance de soi" (Foucault, 1994: 227). Foucault resume em três os tipos de luta neste campo: as lutas face às formas de dominação; as que dizem respeito às formas de exploração que separam o indivíduo daquilo que produz; as lutas que combatem tudo o que liga o indivíduo a si próprio e assegura assim a sua submissão aos outros (cf. loc. cit.).

28 "On a souvent dit que le christianisme avait donné naissance à un code d'éthique fondamentalement différent de celui du monde antique. Mais on insiste en général moins sur le fait que le christianisme a proposé et étendu à tout le monde antique des nouvelles relations de pouvoir. Le christianisme est la seule religion à s'être organisée en Église. Et en tant qu'Église le christianisme postule en théorie que certains individus sont aptes, de par leur qualité religieuse, à en servir d'autres, non pas en tant que princes, magistrats, prophètes, devins, bienfaiteurs ou éducateurs, mais en tant que pasteurs" (ibid. 229). 
No modelo de Foucault, devemos distinguir a figura da instituição eclesiástica, vista em declínio a partir do séc. XVIII, e a função dessa instituição enquanto processo, que ultrapassou as fronteiras do terreno eclesiástico.É neste último sentido que devem ser situadas as observações de Foucault acerca do Estado moderno enquanto matriz de uma nova individualização. É que para Foucault esse Estado não ignora os indivíduos, antes, procura integrá-los de forma providente, reconhecendo a sua individualidade (cf. ibid. 230-32) ${ }^{29}$.

\section{A "paródia" do religioso}

Os recursos fundamentais de encenação do poder permanecem, pois, mas num contexto de dissipação social e de pluralidade de significações favorecidas pelo desenvolvimento do espaço comunicativo público. É este contexto que conduz os críticos de Legendre a afirmar que a nas sociedades secularizadas se desvaneceu a função do Terceiro (Tiers). A sua antropologia do direito recusa a ideia da subsistência de uma sociedade moderna dual, sem a intervenção, portanto, do Terceiro (Tiers) - a mudança de "cena" não implica a negação sem resto da figura da Referência transcendente em relação às transacções entre os indivíduos ${ }^{30}$. À dissipação e pluralidade referidas correspondem novas formas de instituir a imagem. A omnipresença da fotografia e do filme nas sociedades

${ }^{29}$ Esta metamorfose do poder pastoral, que Foucault estuda no contexto da emergência do Estado moderno, pode ser observada também na estrutura do campo religioso. No campo estadualizado, a ideia de uma salvação no além da história é substituída por um conjunto de sentidos intramundanos: saúde e bem-estar, segurança, protecção contra os acidentes. Mas, no que diz respeito ao campo religioso, este ambiente social parece ter favorecido a integração, dentro da ideia de salvação, de ideais de transformação do mundo, mais, de ideais filantrópicos. Também no campo religioso este poder pastoral se desenvolve em duas frentes: uma, globalizante e quantitativa, centrada na população e no território; outra, analítica e qualitativa, que visa o indivíduo. Se é verdade que aquele poder pastoral que estava ligado à instituição eclesiástica se estendeu ao conjunto do corpo social segundo metamorfoses várias analisadas por Foucault, também é certo que esse poder não abandonou o campo religioso e sofreu ele próprio transformações semelhantes. Ou seja, podemos descobrir nas instituições religiosas operações individualizantes semelhantes às que Foucault descobre no Estado moderno através da articulação de poderes múltiplos (a família, a medicina, os saberes "psi”, a educação, etc.). Essa aculturação moderna do poder pastoral religioso, dentro de certos limites de elasticidade política, encontra formas de se adaptar à própria crise recente do crédito dado às instituições, cuja autoridade deve ser vista à luz desta figura do poder pastoral (cf. Teixeira, 2005: 60-64).

30 "La problématique de la séparation, du rapport au monde à travers le voile des mots, est toujours là, et à travers elle, la problématique du Tiers. Prétendre à l'abolition du Tiers, à une société qui ne serait plus q'un agglomérat d'individus en duel les uns avec les autres, s'est comme si on prétendait abolir le miroir". Legendre, 1999: 307). 
hodiernas está ao serviço dos novos dogmas dos espaços da produção e do consumo (cf. Legendre, 1983). "L'image c'est le dogme"31 - o fluxo contínuo de imagens, próprio destas sociedades, aponta para aquilo que é inevitável acreditar e remete-nos para o mito de Narciso: Quem é o outro na imagem? Sou eu ou um outro? Quem é o outro? Quem sou seu? O mesmo efeito de espelho se joga na constituição da esfera pública, cenário dos novos modelos de configuração do sujeito.

A profunda alteração dos quadros sociais da experiência religiosa, a diminuição da capacidade inclusiva das instituições e o peso ideológico das profecias do "fim da religião" podem levar à conclusão fácil de que, com a erosão de determinadas formas históricas de religião, desaparecem as funções simbólicas que nelas se condensavam. É necessário permanecer atento às deslocações do sagrado, uma vez que as religiões históricas viram diminuído o poder de fixar o sentido desse sagrado. Nas condições actuais, a figura da blasfémia surge com frequência traduzida nos diferentes registos da "paródia" do religioso ${ }^{32}$, uma vez que os mitemas religiosos ficaram ao alcance de formas diversas de colonização sem a protecção das antigas autoridades. As produções e as práticas estéticas dão testemunho destas transformações.

A linguagem da crença é um laboratório privilegiado para a observação das relações entre o sistema estético e o sistema religioso. A Jean Wirth pertence um dos mais importantes estudos sobre o uso medieval e moderno do conceito de crença (cf. 1983), estudo que encontrou outros desenvolvimentos na sua obra acerca da imagem na cultura medieva (cf. 1989). O investigador partiu do estudo do vocabulário medieval para mostrar as trajectórias da constituição do vocabulário moderno da crença. Wirth observa que não há no latim medieval nenhuma palavra que cubra o campo de croyance no francês moderno. O campo semântico de fides alargou-se entre os séculos IV e XII, de tal forma que passou a designar tanto o vínculo religioso, quanto o laço social (o juramento, a vassalidade). Wirth mostrou como a arte se tornou um meio de

${ }^{31}$ Legendre, 1999: 311; este o tema central das suas “Lições III”" publicadas em 1994.

${ }^{32}$ Falamos de "paródia" não no sentido de comentário irónico, mas no sentido de "contrafactura", tal como no século XVI era usado para caracterizar processos de composição que partiam de um modelo pré-existente, modelo que por vezes nada tinha que ver com o carácter ou a função da obra final. Estas apropriações podiam afectar o texto (um texto antigo com uma nova música) ou o texto e a música (adaptação e desenvolvimento de uma elemento musical com um texto novo). Veja-se, por exemplo, a utilização da chanson "Malheur me bat" de Ockghem na Missa de Josquin des Prez que tomou o mesmo nome. Na historiografia essa missa é designada, por isso, de "missa de paródia" ou "de imitação", e no seu tempo seria identificada como "missa de imitação (paródia) de Malheur me bat". Paródia não tem pois aqui, um sentido pejorativo, identifica apenas um processo de composição musical (cf. Teixeira \& Delgado, 2003). 
pregação: a arte coopera com as montagens rituais que organizam as acções litúrgicas da Igreja e a imagem torna-se o lugar, por excelência, da produção do sagrado. Em L'image médiévale, Wirth procurou mostrar como, entre o século XI e o século XIII, o sistema estético e o sistema religioso se articulam, de forma mais vasta, com o sistema social (cf. 1989: 343-345) ${ }^{33}$.

A moderna croyance caracteriza-se por uma remodelação profunda das relações entre o sagrado e o profano. Wirth mostra que o conceito de fides será cada vez menos englobante das práticas sociais, isto porque a emancipação das instituições transporta consigo remodelações e inovações semânticas (cf. 1983: 10-14). Assim se assistirá à emancipação do vocabulário das instituições do seu Sitz im Leben original. Entre os séculos XVI e XVII, fides tenderá a designar uma verdade transcendente, ou a relação com ela, que se distingue precisamente da croyance dos outros. Fides especializar-se-á, e croyance alargará de forma pouco coerente o seu campo semântico, designando tanto a convicção interior, quanto a adesão a uma ortodoxia, ou mesmo a relação com o religioso ilegítimo, empurrado para a zona nocturna da superstição. Deixará de existir, portanto, um termo único para designar de forma inalienável lealdades e vínculos religiosos e sociais, talvez porque essa articulação não mais será possível da mesma forma (cf. 1983: 31, 49-53).

Esta transformação no plano da linguagem, inscreve-se no terreno vasto daquilo que Michel de Certeau designou de fragmentação do cristianismo enquanto corpo social - a desagregação social do "cristianismo objectivo" (descrita sob a figura do christianisme éclaté). Certeau falava do fim da articulação estrutural entre a experiência pessoal do crente e a experiência social da comunidade através da Igreja enquanto "corpo de sentido" (cf. Certeau, 1974: 9-13). A consequência seria a ampla disseminação do religioso, contexto em que as convicções amolecem, perdem os seus contornos, acabando por se achar na linguagem comum sob a forma de um exotismo mental, de uma koinê da ficção. Retomando alguns dos tópicos fundamentais da sua antropologia do crer, dir-se-ia que as convicções se acumulam naquela região em que "se diz" aquilo que já "não se faz", região onde se teatralizam os recursos que já se não conseguem pensar, e onde se mesclam necessidades várias, ainda irredutíveis, mas desprovidas de representações credíveis (cf. Idem, 1987a: 183). Este é o

${ }^{33}$ Com uma amplitude maior de informação, Georges Duby tinha já mostrado a importância desse fenómeno nas relações entre arte e sociedade de 980 a 1420, lugar de descoberta de uma concepção espiritualista de imagem que reabilita a matéria como sinal do espiritual (cf. 1976) - este aspecto relaciona-se com a estrutura sacramental das doutrinas de salvação do cristianismo, território que será o lugar de muitas das clivagens religiosas que contextualizarão a(s) Reforma(s). 
contexto em que a elaboração simbólica do sagrado se pode emancipar dos objectos convencionalmente reconhecidos como religiosos, e estes mesmos podem ser matéria para novas recomposições num regime de paródia simbólica em que os mitemas e os ritemas não podem ser já explicados pela lógica do credo que os organizava, ou pelas práticas reguladas que os actualizavam. Neste domínio é necessário ter em conta três tópicos essenciais:

a) A folclorização do cristianismo objectivo (cf. Certeau, 1974: 9-13). Algumas décadas atrás, ainda a crença cristã estava solidamente ancorada em grupos e comportamentos específicos. Não havia lugar para a fluidez dos contornos. Ou se aderia a uma linguagem ou se entrava para as fileiras dos que a combatiam. Antes, o cristianismo definia formas de sociabilidade e práticas particulares, agora esse cristianismo cultural já não está da mesma forma radicado na fé de um grupo particular. A circulação das personagens do religioso na cena pública mediática é bem o exemplo disto mesmo. Não aparecem já como especialistas de um discurso que dá testemunho de uma verdade, mas como mais uma voz no teatro das opiniões desta commedia dell'arte a que agora passámos a chamar sociedade da comunicação. O núcleo do funcionamento dos media, da publicidade e da representação política, encontra-se precisamente nesta alquimia que dá a "ver" o que é necessário "acreditar", definindo o campo, o estatuto, e os objectos da visão. Desta forma, a ficção, outrora limitada aos lugares do estético, invade o quotidiano dizendo real o simulacro que produziu, levando os destinatários não a crer no que não vêem (lógica tradicional), mas a crer no que vêem. Assim se constitui um novo paradigma do saber que define o referente social pela sua visibilidade (ao contrário do antigo postulado da invisibilidade do real), demonstração de uma nova relação entre o crer e o real, que agora é mediada pelo "visto", ou pelo "mostrado". Para este novo paradigma da visualidade, a memória iconográfica religiosa é um vasto stock de sugestões na luta própria do mercado (vide Fig. 5) (4. $^{34}$

${ }^{34}$ O media tornaram-se um poderoso meio de instituição do real (cf. Certeau, 1990: 270-272): nunca outros ministros de Deus puderam falar de forma tão contínua, produzir revelações e regras em nome da actualidade, de tal forma que esse narrar "o-que-se-passa" se tornou a ortodoxia do presente, fábrica de simulacros que produz crenças e, portanto, praticantes: "Le réel raconté dicte interminablement ce qu'il faut croire et ce qu'il faut faire" (Certeau, 1990: 271). Esta dogmática do presente não possui lugar próprio, nem sede ou magistério definido. Ela "cobre o acontecimento", produz as nossas lendas-legendas, transmuta o ver em crer. Esse pluriverso de narrativas jornalísticas, publicitárias, televisivas, mais do que as narrativas teológicas do passado exercem as funções da providência e da predestinação uma vez que imprimem modelos narrativos, que se reproduzem e ampliam: "Notre société est denue une société recitée, en un triple sens: elle est definie à la fois par des récits (les fables de nos publicités et de nos informations), par leurs citations et par leur interminable récitation" (loc. cit). 


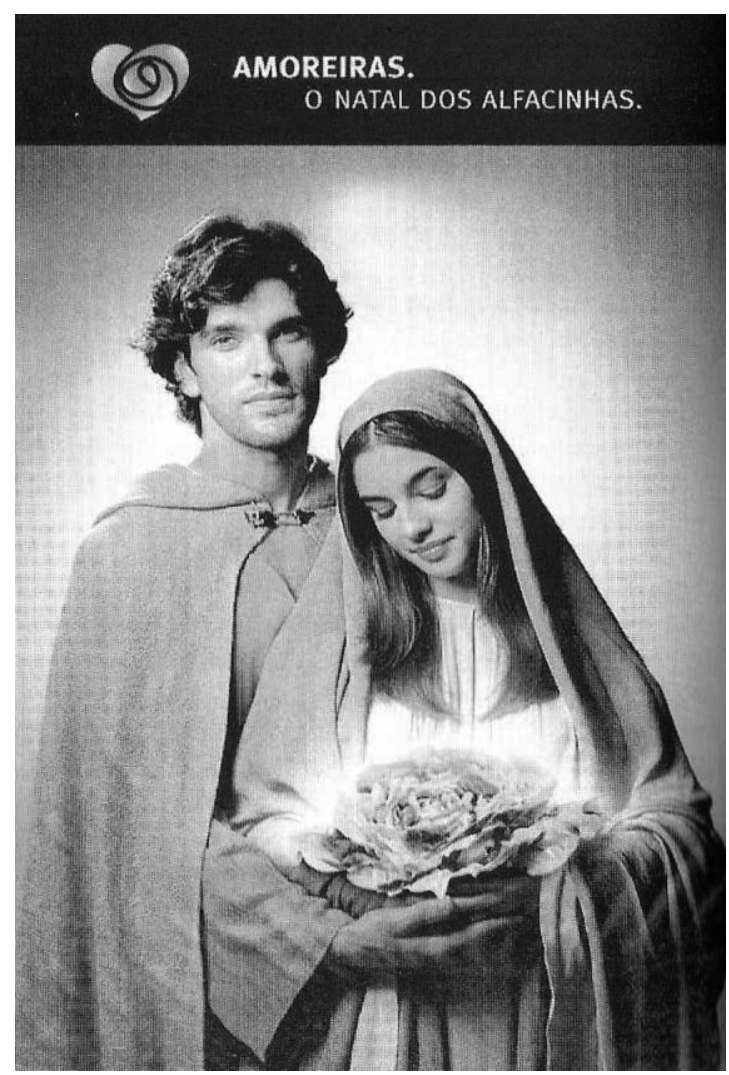

Fig. 5 - Imagem de uma campanha publicitária no Natal de 1999

b) Esteticização do religioso (cf. Certeau, 1974: 18-20). O corpo de escritos e ritos cristãos é utilizado como um conjunto de belas artes servindo os interesses da criação estética: desde as poéticas mais secretas às composições teatrais e musicais, passando pela reinvenção das práticas dos espaços e arquitecturas cristãs. O Livro (a Bíblia), antes inscrita numa experiência crente comum, num modo de "receber" (tradição), de "praticar" (leitura) e de "pensar" (teologia) vê-se agora liberto das amarras que o ligavam a uma fidelidade concreta e vigiada e fica à mercê quer das práticas científicas, comuns ao tratamento de outros textos, quer às invenções das artes.

c) Erosão das fronteiras dos sistemas simbólicos. Este tópico decorre daquilo que Certeau percebeu como uma extensa crise da credibilidade das instituições (cf. 1974: 27-31). Desde há, pelo menos três séculos o "funcionariado" da 
verdade pretendido pelas instituições eclesiais é contestado em sectores da sociedade cada vez mais vastos. Esta dissonância deixou mesmo de necessitar de assumir formas contestatárias: multiplicam-se os "cristãos sem Igreja" mas sem que isso se traduza na constituição, como no séc. XVII, de grupos periféricos que renunciam à mediação eclesial em nome de uma religião mais espiritualizada. Tal como os partidos e os sindicatos, as religiões e as Igrejas vêem afectada a sua capacidade de continuar a exercer duas das suas funções primordiais: organizar as práticas e representar os princípios. É esta degradação da capacidade de gestão institucional do religioso que favoreceu nas últimas décadas, nas sociedades que alguns qualificam de pós-cristãs, a proliferação de doxemas exógenos e o intenso trabalho de bricolage religioso e espiritual ${ }^{35}$. Desprovidos das antigas garantias - políticas, cosmológicas e outras - os sistemas simbólicos vêem-se desprotegidos das fronteiras que os defendiam, ficando o seu património simbólico à mercê de reapropriações diversas em contextos culturais múltiplos.

A arte caricatural do séc. XIX caricatural encontrará na ampla tradição iconográfica cristã um vasto stock de referências que permitirão o exercício da contrafacção humorística ${ }^{36}$. Tome-se como exemplo a "Ascensão" de Alfred Le Petit, mostrando Jesus a subir ao Céu num balão dirigível e representando os Doze e Maria com uma indumentária próxima dos recortes geométricos da pintura dos finais da Idade Média (vide Fig. 6). O plano satírico da caricatura acaba por ser reforçado pela sobrevivência de traços estilísticos que religavam a imagem e a fé numa forte articulação social.

Precisamente porque a história cristã está cheia de imagens da omnipotência de Deus, este movimento de paródia do religioso, que se divulgou de forma mais ampla nas duas últimas décadas do séc. XIX e se prolongou no século XX, acentuou todos os aspectos que pudessem tornar-se exemplares da constituição de uma crítica aos aspectos mais centrais das definições religiosas recebidas. Deus, o infigurável, vê a sua transcendência esvaziada sob a figura de uma marioneta e a sua palavra omnipotente reduzida à habilidade do ventríloquo (vide Fig. 7). Neste contexto histórico, a blasfémia visual pode ser descrita como um meio de luta contra as condições de saturação religiosa do espaço social, portanto, como meio de conquista de liberdade individual face a hegemonia das representações colectivas, usando as tácticas da desfiguração, tantas vezes usadas também no terreno da defesa e expansão da identidade religiosa. A

${ }^{35}$ Sobre o uso da categoria bricolage: cf. Teixeira, 2005: 183-191.

${ }^{36}$ Estudo de Guillaume Doizy (2006) reuniu de forma eficaz uma ampla amostra documental sobre a caricatura anticlerical e a farsa visual sobre temas bíblicos. 


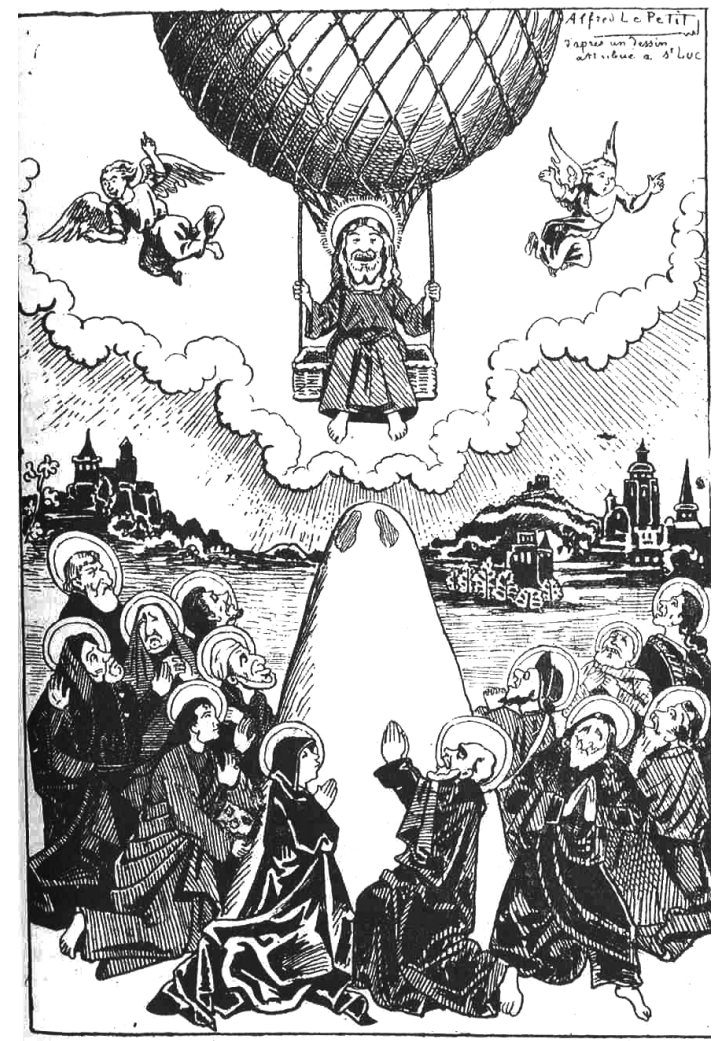

L'ASCENSION DU NOMMÉ ,IESUS-CHRIST

Fig. 6 - “Ascensão”, ilustração de Albert le Petit (Doizy, 2006: 83)

blasfémia e o anátema são expressão de uma violência simétrica. No entanto, a sua eficácia depende de uma associação do político e do religioso que não se reproduz nas sociedades laicizadas. A blasfémia de que se fala aqui deixa de ser um discurso feito a partir de dentro para se tornar um recurso estético, uma vez que o lugar de enunciação é já exterior à normatividade religiosa - esta tornou-se um campo em entre outros, subsistema num ambiente social especializado e complexo (cf. N. Luhmann, 1977).

A "humilhação" e a "desfiguração"da iconografia cristã na arte contemporânea dá testemunho desta possibilidade de instauração de um olhar espectacular sobre o religioso recebido, apropriando-se da memória segundo tácticas combinatórias diversas ou usando essa memória iconográfica para criticar o cristianismo ou, 


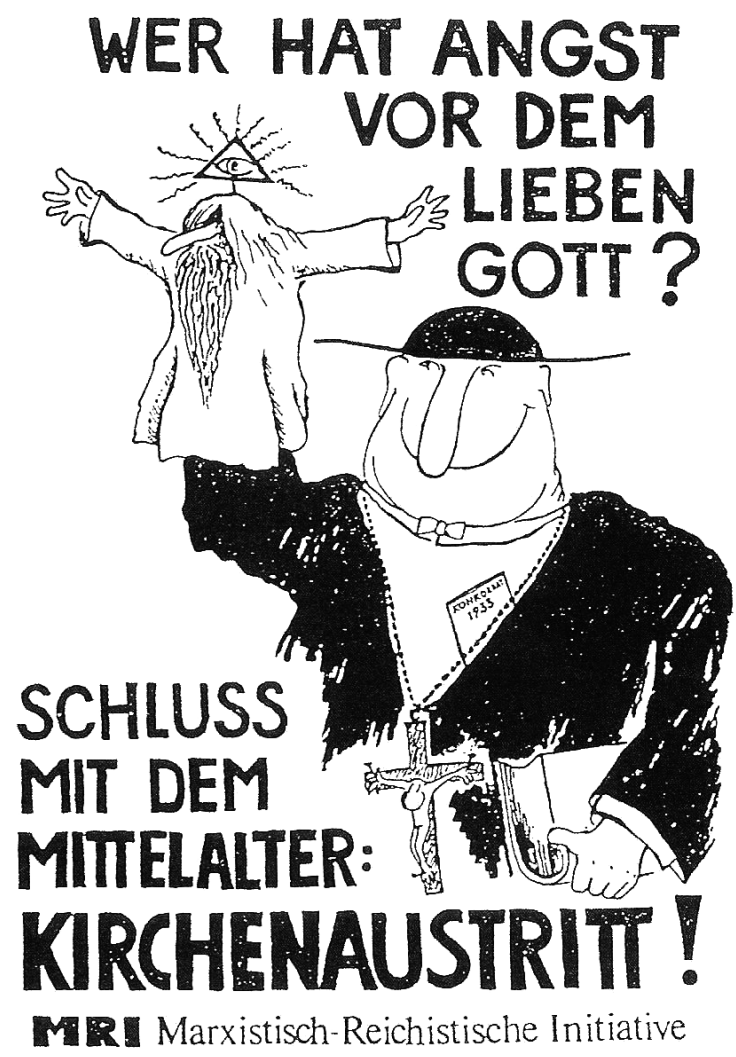

Fig. 7 - Ilustração em Ketzerbriefe, no 10 (Doisy, 2006: 89)

pelo menos, algumas das suas formas históricas. Recordemos como exemplo o quadro surrealista de Max Ernst, "A Virgem castigando o menino Jesus diante de três testemunhas (André Breton, Paul Eluard e o pintor)", de 1926, paródia satírica uma das imagens mais populares do cristianismo, Jesus e sua mãe. Tenha-se presente, também, no filme Viridiana (1961), de Luis Buñuel, a cena em que os mendigos tomam lugar na "Ceia" de Leonardo da Vinci, parodiando uma refeição burguesa. O ímpeto iconoclasta tornar-se-á um dos motores da criação contemporânea. Mas o ímpeto satírico e desconstrutor não 
visa simplesmente uma determinada ortodoxia religiosa, tem como objecto crítico a sintaxe social a que estava amarrado esse sistema simbólico ${ }^{37}$.

Mas as condições sociais que facilitam a esteticização da blasfémia visual, permitem também o uso da expressão visual, sob a figura da caricatura, com outras finalidades. Dir-se-ia que o processo de secularização das sociedades que fizeram a experiência histórica do cristianismo integra a própria secularização interna do campo religioso cristão. O mesmo recurso expressivo servirá para veicular a crítica interna dinamizando um espaço de opinião pública dentro das Igrejas e explorando toda a margem de manobra que aí têm as diásporas ideológicas. Os desenhos do cartoonista José Luis Cortés dão testemunho das fracturas internas relativas, por vezes, à própria representação teológica dos atributos de Deus (vide Fig. 8). A manipulação do humor visual pode estar ao serviço da própria apologia da mensagem cristã. Dirigindo-se assim, não só aos crentes, no interior do campo religioso, mas a um universo mais amplo de interlocutores, o ilustrador traduz a religião em moral, procurando uma linguagem mais inclusiva (vide Fig. 9). A moral humanitária, forma aculturada da ética da fraternidade cristã, apresenta-se, hoje, como um campo de comunicação com condições facilitadas para o encontro do ideologicamente diverso (cf. Habermas, 1981).

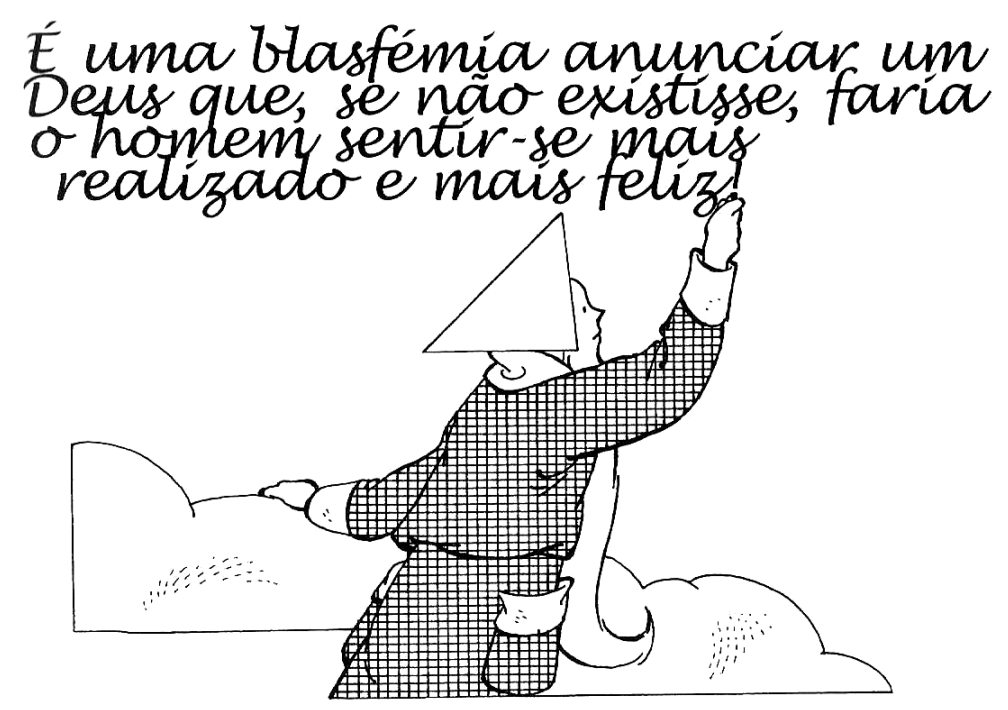

Fig. 8 - Desenho de José Luis Cortés (2005: 27)

${ }^{37}$ A obra de Jérôme Cottin (cf. 2007) sobre a arte e o cristianismo, de 1900 aos nossos dias, reúne um amplo dossier sobre este tema. 

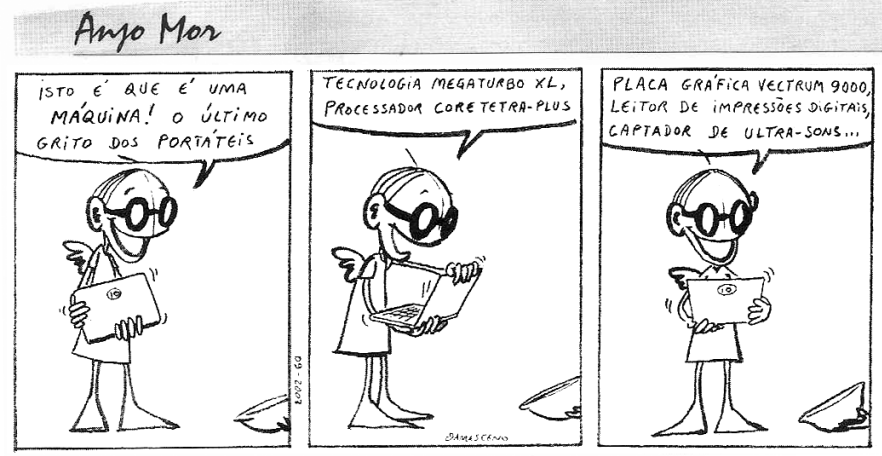

DAMASCENO REIS

Fig. 9 - Tira de Damasceno Reis (Acção Missionária, Outubro de 2007, pág. 9)

\section{Epílogo}

As interrogações acerca da construção social da identidade e da alteridade ganharam renovada relevância depois que acontecimentos recentes trouxeram para a cena pública as figuras de uma violência desmedida cuja simbolização recorre aos imaginários religiosos. Em alguns destes contextos, o factor étnico-religioso, por via da sua extraordinária capacidade de emblematização (totemização), torna-se a bandeira de identidades musculadas que se autocompreendem sob a ameaça do "outro". Porque a produção de imagens serve a emblematização da experiência desse "nós" social, também os confrontos dos mundos se tornam guerras da imagem.

O reforço musculado dos factores étnico-religiosos é, nestas situações, uma estratégia de protecção face à ameaça, real ou imaginada, do Outro. No contexto desta reflexão, é significativo o que Paul Ricœur escreveu acerca da violência simbólica: essa tentativa de forçar a nascente a dobrar-se às dimensões do recipiente, numa operação que considera de autoprotecção face a tudo o que possa aparecer como ameaça do desbordamento, como ameaça do excesso. Ricœur põe em destaque esse trabalho próprio do crente - quando se encontra dentro de uma denominação confessional - que é o de reforçar as paredes do espaço de acolhimento perante esse excesso percebido como ameaça - na impossibilidade de vedar o topo, reforçam-se os lados, vedam-se as fendas (cf. Ricœur, 2000: 29). A exacerbação das identidades religiosas pode ser vista como o sublinhado de uma linha de fronteira que, em vez de permitir a comunicação, quer fazer crer que para além da linha está o vazio. Reforçar as 
muralhas significa, neste caso, conter pela força os que estão dentro e expulsar todos os que se não deixam controlar ${ }^{38}$.

Assim a violência, neste contexto, pode ser lida como uma tentativa de protecção contra a ameaça de desenraizamento, contra o medo da indiferenciação, percurso em que a comunidade de acolhimento se torna comunidade de apresamento. No terreno dos monoteísmos, as palavras de Ricœur ganham uma particular pertinência:

Todas as outras comunidades históricas que se reclamam de um mesmo transcendente, mas nos termos de uma outra confissão, aparecem como rivais na luta pela apropriação do Ser, do Outro absoluto, tratado como um mesmo a possuir com exclusão dos outros. Então, as outras comunidades são rivais nesse desejo-temor, no acolhimento possessivo redutor da transcendência [...]. Daí a exclusão das outras comunidades consideradas como ímpias, heréticas, impuras, etc. Os exemplos abundam nas imediações do monoteísmo, diria até que sobretudo nessa área, quer se trate da luta do yavismo contra Baal, os massacres dos sacerdotes de Baal no livro de Josué, a competição entre a sinagoga e a igreja dos primeiros séculos, os assassínios rituais de judeus na Europa cristã da Idade Média e as guerras de religião no interior da cristandade, do séc. XVI ao séc. XVIII” (Ricœur, 2000: 34).

A construção da identidade e da alteridade, nos novos quadros sociais, irá porventura exigir dinamismos que visem um duplo efeito: (teológico) «desabsolutização» do divino; (político) «desabsolutização» das identidades. Neste quadro se poderão aprofundar as condições de uma laicidade mediadora que permita a construção do político no contexto dos novos pluralismos.

${ }^{38}$ Este pequeno texto de Michel de Certeau exprime de forma lapidar este processo: "Toda a sociedade se define pelo que exclui. Constitui-se diferenciando-se. Formar um grupo é criar estrangeiros. Uma estrutura bipolar, essencial para toda a sociedade, supõe um fora para que exista um entre nós; fronteiras, para que se desenha um país interior; outros, para que um nós tome corpo. Esta lei é, também, um princípio de eliminação e de intolerância, conduz à dominação, em nome de uma verdade definida pelo grupo" (1991: 14). 


\section{Bibliografia}

BCESPFLUG, François (2006). Caricaturer Dieu? Pouvoirs et dangers de l'image. Paris: Bayard.

BOURDIEU, Pierre (1982). Ce que parler veut dire: L'Économie des échanges linguistiques. Paris: Fayard.

CERTEAU, Michel (1990). L'Invention du quotidien: I. Arts de faire. Paris:

Gallimard [1980].

- (1987). La faiblesse de croire, Paris: Seuil.

- (1974). Le christianisme éclaté (en collaboration avec Jean-Marie Domenach).

Paris: Seuil.

CERTEAU, Michel de (1991). L'Étranger ou l'union dans la différence. Paris:

Desclée de Brouwer [1966].

- (1990). L'Invention du quotidien: I. Arts de faire. Paris: Gallimard [1980].

- (1987a). La faiblesse de croire, Paris: Seuil.

- (1987b). La Fable mystique, 1. XVI ${ }^{\mathrm{e}}$-XVII ${ }^{\mathrm{e}}$. Paris: Gallimard [1982].

- (1983). L'institution du croire. Note de travail, in: Recherches de Science Religieuse 71, 61-80.

- (1981). Croire: une pratique de la différence. Documents de travail et prépublications A 106. Urbino: Centro Internazionale di Semiotica e di Linguistica [=Une pratique social de la différence: croire, in: Faire croire. Modalités de la diffusion et de la réception des messages religieux du XIII ${ }^{e}$ au XV $V^{E}$ siècle, Rome: Ecole Française de Rome 1981, 363-383].

- (1974). Le christianisme éclaté (en collaboration avec Jean-Marie Domenach). Paris: Seuil.

COTTIN, Jérôme (2007). La mystique de l'art: art et christianisme de 1900 à nos jours. Paris: Cerf.

DOBBELAERE, Karel (1981). Secularization: A Multi-Dimensional Concept. London: Sage Publications.

DOISY, Guillaume (2006). De la caricature anticléricale à la farse biblique. Archives de Sciences Sociales des Religions, 51: 134, 63-91.

DUBY, Georges (1976). Le temps des cathédrales: l'art et la société, 980-1420. Paris: Gallimard.

FOUCAULT, Michel (1994). Le sujet et le pouvoir. In: Dits et écrits IV (1954-1988). Paris: Gallimard, 222-243.

GIMARET, Daniel (1997).Dieu à l'image de l'homme: Les anthropomorphismes de la sunna et leur interprétation par les théologiens. Paris: Cerf.

GIRARD, René (2002). La voix méconnue dus réel: une théorie de mythes archaïques et modernes. Paris: Grasset. 
- (1999). Je vois Satan tomber comme l'éclair. Paris: Grasset.

- (1982). Le bouc émissaire. Paris: Grasset.

- (1978). Des choses cachées depuis la fondation du monde. Paris: Grasset.

- (1972). La Violence et le Sacré. Paris: Grasset.

GOODY, Jack (1997). Representations and Contradictions: Ambivalence

Towards Images, Theatre, Fiction, Relics and Sexuality. Oxford: Blackwell Publishers.

GRABAR, O. (1992) - The Mediation of Ornament. Princeton.

HABERMAS, Jürgen (1981). Theorie des kommunikativen Handels I-II.

Frankfurt: Suhrkamp.

KANTOROWICZ, Ernst (1984). Mourir pour la Patrie. Paris: PUF.

- (1957). The King's Two Bodies: A Study in Mediaeval Political Theology. Princeton University Press.

LABBÉ, Yves (1984). La Parole-Icône incréée: Essai de théologie trinitaire selon l'ordre du langage. Revue des Sciences Philosophiques et Théologiques, 68, 321-352.

LUHMANN, Niklas (1977). Funktion der Religion. Frankfurt: Suhrkamp.

LEGENDRE, Pierre (1999). Sur la question dogmatique en Occident. Aspects théoriques. Paris: Fayard.

- (1994). Leçons III. Dieu au miroir. Étude sur l'institution des images. Paris: Fayard.

- (1992). Leçons VI. Les Enfants du Texte. Étude sur la fonction parentale des États. Paris: Fayard.

- (1988). Leçons VII. Le désir politique de Dieu. Étude sur les montages de l'État et du Droit, Paris: Fayard.

- (1985). Leçons IV.L'Inestimable objet de la transmission. Étude sur le principe généalogique en Occident. Paris: Fayard.

- (1983). Leçons II. L'Empire de la vérité. Introduction aux espaces dogmatiques industriels. Paris: Fayard.

- (1974). L'Amour du censeur. Essai sur l'ordre dogmatique. Paris: Seuil.

LEMIEUX, Raymond (1992). Foi et religion: une lecture sémiologique. In: Michel DESPLAND \& Gérard VALLÉE, éd., Religion in History: The Word, the Idea, the Reality. Waterloo: Wilfrid Laurier University Press, 169-191.

LUIS CORTÉS, José (2006). Um Deus chamado Abba. Cruz Quebrada: Estrela Polar.

RICEUR, Paul (2000). A Religião e a Violência. Revista Portuguesa de Filosofia, 56, 25-35.

SACHOT, Maurice (1998). L'invention du Christ. Paris: Éd. Odile Jacob. 
TEIXEIRA, Alfredo (2006). Os “índios do interior”: A instituição do crer e a folclorização do religioso segundo Michel de Certeau. Didaskalia, 36: 2, 165-193.

- (2005). «Entre a exigência e a ternura»: uma antropologia do habitat institucional católico. Lisboa: Paulinas.

-\& Cristina DELGADO (2003). A emancipação do sagrado e a paródia do religioso. Notas exploratórias sobre a criação musical na segunda metade do século XX. Revista Portuguesa de Ciência das Religiões 2, 35-62.

- (2003). Identidade e diferença. A violência enquanto substrato da vida social nativa. In: Religiões: Identidade e Violência. Actas da XXIII Semana de Estudos Teológicos, 4-6 de Fevereiro de 2002. Lisboa: Alcalá, Faculdade de Teologia da Universidade Católica, 51-68.

- (2002). Narrar a origem e instituir a diferença. Perspectivas religiológicas. Revista Portuguesa de Ciência das Religiões, 1:1, 105-119.

- (1995). A pedra rejeitada. O eterno retorno da violência e a singularidade da revelação evangélica na obra de René Girard. Porto: UCP, Fundação Eng ${ }^{\circ}$ António de Almeida.

TSCHANNEN, Olivier (1992). Les théories de la sécularisation. Genève, Paris: Librairie Droz.

WAGTENDONK, K. (1987). Images in Islam: Discussion of a Paradox. In: D. Van der PLAS, Effigies Dei. Essays on the History of Religions. Leyde, 112-129.

WIRTH, Jean (1983). L'évolution du concept de croyance. Bibliothèque d'Humanisme et Renaissance 45.

- (1989). L'image médiévale: naissance et développements (VIe-XVe siècle). Paris: Méridien Klincksieck. 